
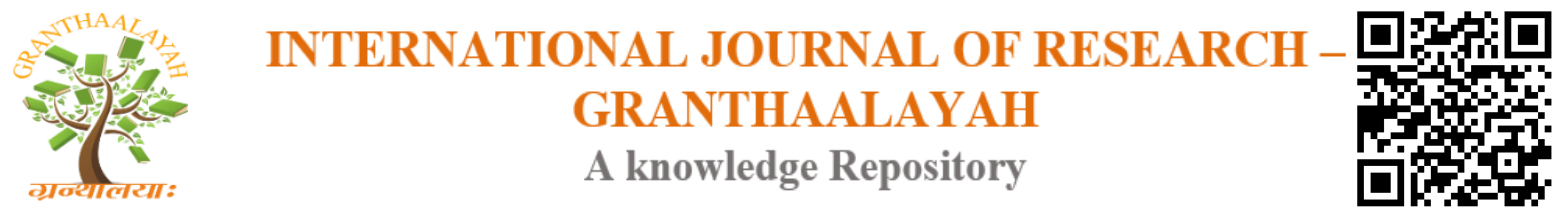

Management

\title{
THE EFFECT OF WORK ENVIRONMENT ON EMPLOYEE PERFORMANCE THROUGH WORK DISCIPLINE
}

\author{
Elok Mahmud Putri ${ }^{1}$, Vivin Maharani Ekowati ${ }^{2}$, Achmad Sani Supriyanto ${ }^{3}$, Zaim \\ Mukaffi ${ }^{4}$ \\ ${ }^{1}$ Department of Management Faculty of Economics UIN Maulana Malik Ibrahim Malang \\ ${ }^{* 2,3,4}$ Faculty of Economics UIN Maulana Malik Ibrahim Malang
}

\begin{abstract}
With the existence of a conducive and comfortable work environment, will create enthusiasm from employees in work and will improve performance and work discipline in each his job. Comfortable work environment, adequate facilities, and good employee relations. Will affect employee performance. When employees feel comfortable with the environment in which they work will certainly bring them to be more disciplined and can improve their performance in achieving the goals of the company/agency. The purpose of this study is to find out (1) the influence of the work environment on employee performance (2) the influence of the work environment on work discipline (3) work discipline mediates the influence of the work environment on employee performance.

This research uses a quantitative approach that is useful for researching the population and samples within a company, where in this study using proportional random sampling as a sampling techniques. The population in this study amounted to 208 employees. And a sample of 137 respondents from PT. GatraMapan. Methods of research data collection used questionnaires. Data analyzed with Path Analysis. The results of this study prove that work discipline is able to mediate the influence of the work environment on employee performance.
\end{abstract}

Keywords: Work Environment; Employee Performance; Work Discipline; Path Analysis.

Cite This Article: Elok Mahmud Putri, Vivin Maharani Ekowati, Achmad Sani Supriyanto, and Zaim Mukaffi. (2019). "THE EFFECT OF WORK ENVIRONMENT ON EMPLOYEE PERFORMANCE THROUGH WORK DISCIPLINE.” International Journal of Research - Granthaalayah, 7(4), 132-140. https://doi.org/10.29121/granthaalayah.v7.i4.2019.882.

\section{Introduction}

Parlinda and Wahyuddin (2001) described the success or failure of a company in achieving its objectives depends on its HR. PT. GatraMapan is one of the companies engaged in manufacturing products furniture entertainment. In general, its activities include the design, production and marketing processes. In maintaining and improving the performance of its employees in order to have a positive impact on the company, of course, they must pay more attention to the factors that 
can affect the performance of their employees such as work discipline and a conducive work environment.

Work discipline according to Veithzal (2006: 444) is a tool used by managers to communicate with employees so that they are willing to change behavior and as an effort to increase one's awareness and willingness to comply with all company regulations and applicable norms. According to Fathoni (2006: 126) discipline is a person's awareness and willingness to obey all company regulations.

In addition to work discipline, the work environment is also one of the factors that can affect employee performance. A good working environment will make employees feel comfortable at work. Convenience will certainly have an impact on improving employee performance. Conversely, the inconvenience of the work environment experienced by employees can be fatal, namely the decline in the performance of the employee itself (Susilaningsih, 2013).

According to Veithzal (2006: 309) performance is a very important thing in the company's efforts to achieve its goals. According to Bintoro and Daryanto (2017) performance is the result of work in quality and quantity achieved by an employee in carrying out his duties in accordance with the responsibilities given to him.

Dessler (2000: 41) stated employee performance is a comparison between work results with standards and those set. While the performance of employees according to (Simamora, 2005: 339) basically refers to the level of achievement of the tasks that make up an employee's work. Performance reflects how well the employee meets the requirements of a job.

The research conducted by Liyas and Reza (2017) explains that there is an influence of work discipline on employee performance. Rivky's research, et al. (2015) also shows that work discipline has a significant effect on employee performance.

Budianto and Amelia (2015) the results of the study show that the work environment found in the company can have a positive and significant influence on employee performance. Hermawan et al. (2018) the results of the study show that the work environment has a direct and positive effect on discipline.

Kholil, et al. (2014) the results of the study stated that work environment variables simultaneously influence employee performance. However, Logahan's research (2012) shows the results of research that the work environment does not have a significant effect on employee performance. From the various contradictions that have been presented before, this study aims to find out whether the work environment can affect employee performance through work discipline.

PT. Gatra Mapan working hours have been determined, either for five working days or six working days according to what is stipulated in the book "Collective Labor Agreement (PKB). But in reality there are some employees who still behave disobediently working hours and regulations that have been set. For example, going home early due to permission to mourn half a day and not returning to the company, arriving late at the company, there were still employees who were absent without information, and throwing cigarette butts in the area of the company or not throwing them in place. 
This shows that there is still a lack of employee awareness of the importance of work discipline and the rules that apply in work.

Based on the observations obtained, it can be concluded that in general the physical condition of PT. Gatra Mapan can be said to be good, although there are still some office spatial plans that are not good or not neatly arranged, for example with the size of office space that is not too wide, so the layout between one table and another is not too far (close). In addition to the coloring of the room there are still some that do not match the color that should be.

\section{Literature Review}

Sedarmayanti (2001) states that broadly the type of work environment is divided into 2 namely: Physical and non-physical work environments. The explanation of the physical work environment, namely, all physical conditions that are around the workplace that can affect the performance of employees both directly and indirectly.

While the non-physical work environment all the conditions that occur are related to work relationships, both with supervisor relationships and with coworkers' relationships or with relationships with subordinates.

According to Moeheriono (2009: 60) performance is a description of the level of achievement of the implementation of an activity program or policy in realizing the goals, objectives, vision and mission of the organization as outlined through the strategic planning of an organization. Understanding performance is the result of work in quality and quantity achieved by an employee in carrying out its functions in accordance with the responsibilities given to him (Mangkunegara, 2007: 9).

Wirawan (2009: 6) explained there are 3 factors that affect the performance of an employee, namely internal organizational environmental factors, organizational external environmental factors and employee internal factors.

Tohardi (2002), discipline is the driving force of employees. In order for each work to run smoothly, it must be endeavored so that there is good discipline. the work environment can be interpreted as the influencing forces, both directly and indirectly to the performance of an organization or company.

Fathoni (2006: 126) discipline is a person's awareness and willingness to obey all company regulations. Mangkunegara (2005: 129) states that there are 2 forms of work discipline, namely preventive work discipline, and corrective work discipline.

\section{Effect of the Work Environment on Employee Performance}

According to Bambang (1991) the work environment is one of the factors that influence the performance of an employee. The research conducted by (Ali, 2015) states that the results of the research show that the work environment in the agency can have a positive and significant influence on employee performance. Budianto and Amelia (2015) state that the work environment influences employee performance. 


\section{H1: Work Environment influences Employee Performance}

\section{Effect of Work Environment on Work Discipline}

According to Fathoni (2006: 126) discipline is the awareness and willingness of someone to obey all company regulations. According to Hasibuan (2007: 193) discipline is the most important operative function of human resource management because the better the discipline of employees, the higher the work performance achieved. The research conducted by Liyas and Reza (2017) explains that there is an influence of work discipline on employee performance. Rivky's research, et al. (2015) also shows that work discipline has a significant effect on employee performance.

\section{H2: Work Environment influences Work Discipline Work}

\section{Discipline Mediates the Relationship Between Work Environment and Employee Performance}

The influence of the work environment is everything or elements that can directly or indirectly affect the company will have a good or bad impact on employee performance. Satrohadiwirjo (2002: 295), states that there is a high correlation between work discipline and the performance of a person. This means that the better the work discipline, the better the performance of someone. According to Kholil, et al (2014) the results of his research state that disciplinary variables and work environment simultaneously influence the performance of employees at PT. Inti Mighty Plasma Works Tapung.

H3: Work Discipline mediates the influence of the Work Environment on Employee Performance

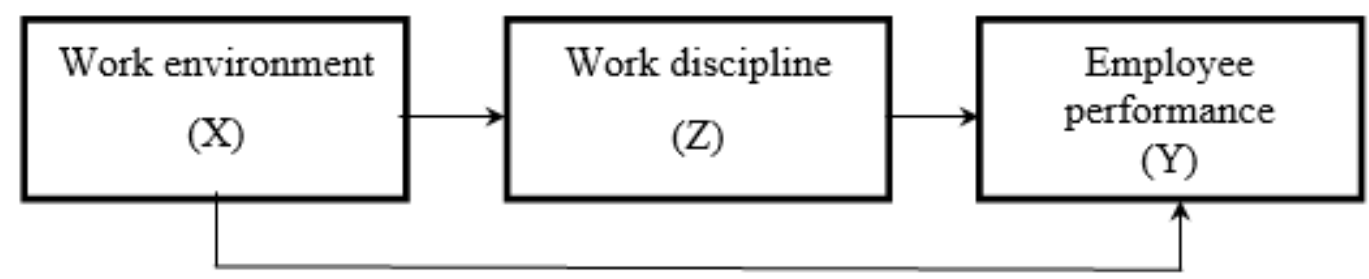

Figure 1: Model Hypothesis

\section{Materials and Methods}

This study uses a survey research method with a quantitative approach. This research was conducted at PT. GatraMapan, which is addressed at JL. Tegal Mapan No.18 Pakis-Malang. The population in this study amounted to 208 employees. Obtained as many as 137 parts by using the Slovin formula according to Umar in Sani (2013: 38).

The sampling technique used in this study is the Proportional Random Samplingtechnique, which is a sampling technique in which all members have equal opportunities to be sampled, according to their proportions, many or few populations (Sugiyono, 2002). The technique of collecting data uses methods that are analyzed using path analysis. 


\section{Results and Discussions}

Table 1: Multicollinearity Test Results

\begin{tabular}{|l|l|l|l|}
\hline \multirow{2}{*}{ Model } & \multicolumn{3}{|l|}{ Collinearity Statistics } \\
\cline { 2 - 4 } & Tolerance & VIF \\
\hline \multirow{2}{*}{1} & (Constant) & & \\
\cline { 2 - 4 } & work environment. & 861 & 1,162 \\
\hline & employee performance. & 861 & 1,162 \\
\hline
\end{tabular}

Based on the results of testing the assumption of multicollinearity, VIF values of all independent variables are less than 5, this means independent variables used in this study did not occur multicollinearity.

To test whether in a regression model variance of the residual inequality occurs, from one observation to another observation. If a different variant is called heteroskedastsitas. A good regression model does not occur heteroscedastity. Detect the presence of heteroscedastsitas by seeing whether there is a certain pattern on the graph, where the $\mathrm{X}$ axis is $\mathrm{Y}$ predicted, and the $\mathrm{X}$ axis is residual.

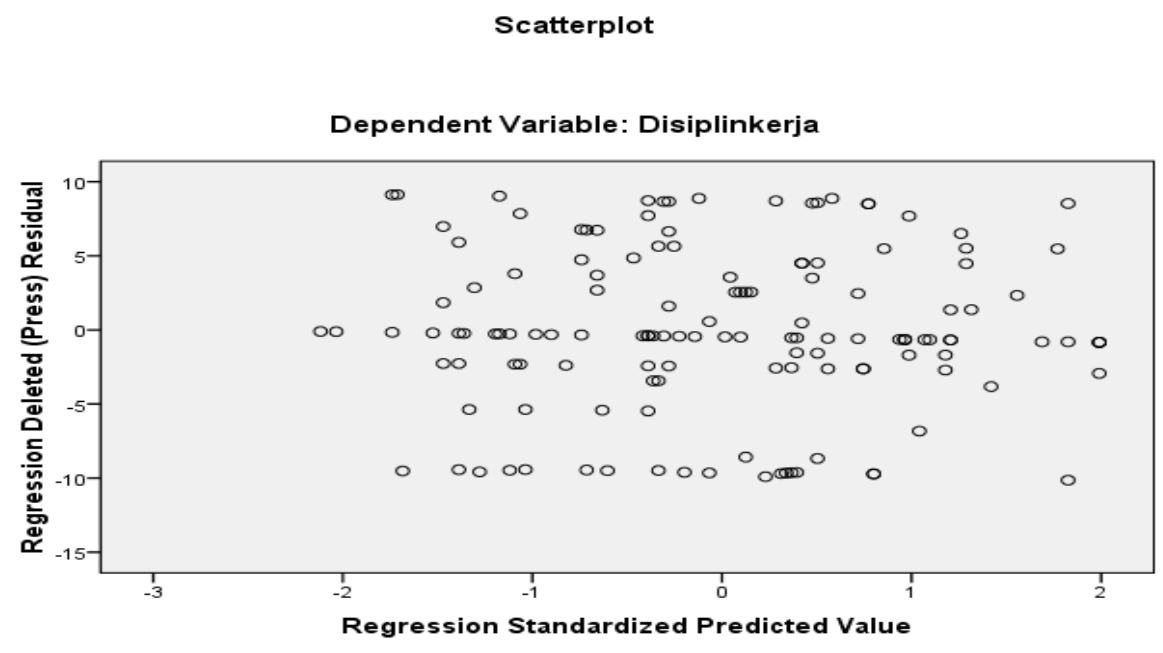

Figure 2: Heteroskedastsitas

\section{Test for autocorrelation}

Based on Durbin Watson's numbers, with the following conditions:

DW numbers below -2 means there is positive autocorrelation.

The DW number between -2 to +2 means there is no autocorrelation.

The DW number above +2 means there is a negative autocorrelation 
Table 2: Test Results autocorrelation

\begin{tabular}{|l|l|l|}
\hline Model & DW & autocorrelation \\
\hline $\begin{array}{l}\text { Work environment } \\
\text { Employee performance }\end{array}$ & 1,570 & Nothing happens \\
\hline
\end{tabular}

Table 3: Results Normality Test

\begin{tabular}{|l|l|l|}
\hline Model & Significance & Normality \\
\hline Work Environment & 0.635 & data were normally distributed \\
\hline Employee Performance & 0.815 & data were normally distributed \\
\hline Commitment Work & 0.202 & data were normally distributed \\
\hline
\end{tabular}

Test results of normality by Kolmogorov -Smirnov can be known by the sig significance value on both models $>0.05$ so that the result is normal.

\section{Linearity Test}

Basicdecision making for linearity tests are as follows:

1) If Sig. or Significance in Devition from Linearity> 0.5, the relationship between variables is linear.

2) If Sig. or Significance in Devition from Liniearity<0.5, the relationship between variables is not linear (Sarjono and Julianita, 2011: 80).

Table 4: Linearity Test Results

\begin{tabular}{|l|l|l|}
\hline Variables & Influence & Description \\
\hline $\mathrm{X}$ to $\mathrm{Z}$ & Sig & $0.977>0.05$ \\
\hline $\mathrm{X}$ to $\mathrm{Y}$ & Sig & $0.786>0.05$ \\
\hline $\mathrm{Z}$ to $\mathrm{Y}$ & Sig & $0.210>0.05$ \\
\hline
\end{tabular}

From the table above it can be concluded that model 1, namely path $\mathrm{X}$ to $\mathrm{Z}$ obtained the value of Significance at Liniearity of 0.977 the data shows that linearity is fulfilled. Model 2, namely path $\mathrm{X}$ to Y, obtained the value of the Significance of Deviation from Liniearity of 0.786, the data shows that linearity is fulfilled. While model 3, namely the $\mathrm{Z}$ line to $\mathrm{Y}$, the value of the Significance Deviation from Liniearity of 0.210 indicates that linearity is fulfilled.

\section{The Effect of Work Environment on Employee Performance}

Based on the results of the path analysis test, it shows that the work environment variable has a significant effect on employee performance $(p=0,000<0,05)$. Variation in changes in value of employee performance variables which can be explained by independent variables of 0.461 .

The results of this study support the research conducted by Budianto and Amelia (2015) from the results of the study showing that the work environment influences employee performance. The results of this study also support the research conducted by Ali (2015), the results of the study state that the work environment found in agencies can have a positive and significant influence on employee performance.

A good work environment, adequate facilities, and a conducive workplace and good relationships with colleagues and superiors will provide comfort to employees. When employees feel 
comfortable and there is support from their social environment, employees will be encouraged to work well.

\section{Direct Effect of Work Environment on Work Discipline}

Based on the results of path analysis tests, it shows that the work environment variable has a significant influence on work discipline $(\mathrm{p}=0.003<0.05)$. Variation in the change in value of employee performance variables which can be explained by independent variables of 0.064 .

The research conducted by Liyas and Reza (2017) explains that there is an influence of work discipline on employee performance. Rivky's research, et al. (2015) also shows that work discipline has a significant effect on employee performance.

Research conducted by Hermawan, et al (2018), the results of his research state that the work environment has a positive direct effect on discipline. The results of this study also support the research conducted by Inbar et al. (2018), the results of the study state that the work environment has a positive and simultaneous effect on work discipline of $0.586(58.6 \%)$.

Thus, that a well-implemented work environment will have a major influence on employee discipline. A bad work environment will lead to the tendency of employees to act undisciplined. The worse the work environment the lower the possibility of work discipline done by employees.

\section{Work Discipline Mediates the Effect of Work Environment on Employee Performance}

In mediation tests on work discipline variables there are results that work discipline variables as mediating variables. After doing the sobel test using Sobel Test Online get a result of 3.48770898 which means greater $>1.98$. This shows that work discipline is able to be a mediating variable on the influence of the work environment on employee performance.

The results of this study support the research conducted by Inbar et al. (2018), that the results of his research state that there is a significant effect of the work environment on work discipline. The results of this study support the theory presented by Sutrisno (2010) which explains that in general the discipline shows a condition or attitude of respect that exists on employees towards the company's rules and regulations.

This study also supports the theory of Satrohadiwirjo (2002: 295), that there is a high correlation between work discipline and the performance of a person. This means that the better the work discipline, the better the performance of someone.

\section{Conclusions and Recommendations}

Conclusions obtained from this study are: (a) Work environment influences employee performance (b) Work environment influences work discipline (c) Work discipline mediates the influence of the work environment on employee performance. The presence of work discipline on the work environment and employee performance is very important, this is because work discipline is a reinforcement of performance or benchmarks. With the existence of employees who are always disciplined in their work, of course, they will further improve performance in the company. And with a comfortable environment will bring employees to be more disciplined. 
There are various limitations in this study so that the findings cannot provide a comprehensive picture. (1) There are other variables that can affect employee performance and work discipline that are not examined, making it possible for other researchers to examine the same problem by adding other independent variables. (2) Work discipline is further enhanced by way of prioritizing regulations that have become the company's operational standards, so that all forms of work can be carried out effectively and efficiently.

\section{References}

[1] Ali, Muhammad Syarif. 2015. Kinerja Pengawas SMA/SMK Ditinjau Dari Lingkungan Kerja Dan Motivasi Kerja Di Wilayah Kaili. Jurnal Penelitian dan Evaluasi Pendidikan. 2015.

[2] Bambang kusrianto Meningkatkan Produktifitas karyawan. Putaka Binaman Pressindo Jakarta. 1991.

[3] Bintoro, dan Daryanto. Manajemen Penilaian Kinerja Karyawan. Yogyakarta: Gava Media; 2017.

[4] Budianto, Aji Tri dan Amelia Katini. Pengaruh Lingkungan Kerja Terhadap Kinerja Pegawai Pada PT. Perusahaan Gas Negara (Persero) Tbk SBU Distribusi Wilayah Jakarta. Jurnal Ilmiah. 2015; Vol. 03, No. 01.

[5] Dessler, Gary. Manajemen Sumber Daya Manusia, Edisi Terjemahan. Jakarta: PT Prenhallindo; 2000.

[6] Fathoni, Abdurrahmat. Manajemen Sumber Daya Manusia. Bandung: Rineka Cipta; 2006.

[7] Hasibuan, Malayu SP. Manajemen Sumber Daya Manusia (Edisi Revisi). Jakarta: PT. Bumi Aksara; 2007.

[8] Hermawan, David, dkk. Pengaruh Supervisi dan Lingkungan Kerja Terhadap Disiplin Guru PNS Gugus 1 Sawangan di Kecamatan Sawangan Kota Depok. Jurnal Pendidikan. 2018; Vol.02, No.03

[9] Inbar, Noor Rika, dkk. Pengaruh Lingkungan Kerja Terhadap Disiplin Kerja dan Semangat Kerja Karyawan (Studi Pada Karyawan PDAM Kota Malang). Jurnal Administrasi Bisnis. 2018; Vol. 58, No. 02

[10] Kholil, M Abdul. Pengaruh Disiplin Dan Lingkungan Kerja Terhadap Kinerja Karyawan Pabrik Pada PT. IntiKarya Plasma Perkasa Tapung. FEKOM. 2014; Vol. 01, No. 02.

[11] Liyas, Nata Reza dan Reza Primadi. Pengaruh Disiplin Kerja Terhadap Kinerja Karyawan Pada Bank Perkereditan Rakyat. Jurnal Lembaga Keuangan dan Perbankan. 2017; Vol. 02, No. 01

[12] Logahan, Jerry M. Analisis Pengaruh Lingkungan Kerja Dan Pemberian Kompensasi Terhadap Kinerja Karyawan CV MUM Indonesia. Jurnal Ekonomi. 2012; Vol. 03, No. 01

[13] Mangkunegara, Anwar Prabu. Manajemen Sumber Daya Manusia Perusahaan. Bandung: PT. Remaja Rosda karya. 2005.

[14] Mangkunegara, Anwar Prabu. Evaluasi Kinerja Sumber Daya Manusia. Bandung: PT. Refika Aditama. 2007.

[15] Moeheriono. Pengukuran Kinerja Berbasis Kompetensi. Bogor: Ghalia Indah. 2009.

[16] Parlinda dan Wahyuddin. Pengaruh Kepemimpinan, Motivasi, Pelatihan, dan Lingkungan Kerja Terhadap Kinerja Karyawan Pada Perusahaan Daerah Air Minum Kota Surakarta. Thesis, Universitas Muhammadiyah Surakarta. 2001.

[17] Rivky, Pomalingo, dkk. Pengaruh Disiplin Kerja, Kompetensi, dan Motivasi Terhadap Kinerja Pegawai Pada Kantor Badan Penanggulangan Bencana Daerah Provinsi Sulawesi Utara. Jurnal Berkala Ilmiah Efisiensi. 2015; Vol. 15, No. 05

[18] Veithzal. Rivai. Manajemen Sumber Daya Manusia Untuk Perusahaan (Dari Teori Ke Praktik). Jakarta: PT. Raja Grafindo Persada. 2006.

[19] Sastrohadiwiryo, Siswanto, B. Manajemen Tenaga Kerja Indonesia. Edisi 2. PT. Bumi Aksara; Jakarta. 2002.

[20] Sedarmayanti. Sumber Daya Manusia dan Produktivitas Kerja. Bandung: CV. Mandar Maju. 2001.

[21] Simamora, Henry. Manajemen Sumber Daya Manusia. Yogyakarta: STIE. 2005. 
[22] Sugiyono. Metode Penelitian Bisnis. Penerbit Alfabeta: Bandung. 2002.

[23] Supriyanto, Achmad Sani dan MasyhuriMachfudz. Metodologi Riset Sumber Daya Manusia. Malang: UIN Maliki Press. 2010.

[24] Supriyanto, Achmad Sani dan Vivin Maharani. Metodologi Riset Sumber Daya Manusia Teori, Kuisioner, dan Analisis Data. Malang: UIN Press. 2010.

[25] Sutrisno, Eddy. Manajemen Sumber Daya Manusia. Jakarta: Kencana. 2009.

[26] Tohardi, Ahmad. Pemahaman Praktis Manajemen Sumber Daya Manusia. Bandung: CV. Mandar Maju. 2002.

[27] Wirawan. Evaluasi Kinerja Sumber Daya Manusia: Teori, Aplikasi, Dan Penelitian. Jakarta: Salemba IV. 2009.

*Corresponding author.

E-mail address: vivien.maharani@ yahoo.com 